\title{
The International Convention on Elimination of All Forms of Racial Discrimination - Reviewing Special Measures Under Contemporary International Law
}

\author{
Medes Malaihollo*
}

DOI: $10.21827 / 59 \mathrm{db} 6930 \mathrm{da} 8 \mathrm{~d} 4$

\begin{abstract}
Racial discrimination is a controversial subject in society and in contemporary international law. Nonetheless, the prohibition of racial discrimination has been universally accepted and States should do everything to prevent racial discrimination. Although protection therefrom cannot be explicitly found in fundamental human rights instruments such as the Universal Declaration of Human Rights, the International Social and Cultural Rights, these documents do, however, include the broader concept of equality and non-discrimination. Nevertheless, a more specific binding legal document exists that addresses racial discrimination, namely the International Convention on the Elimination of All Forms of Racial Discrimination. This document sets out the legal framework of racial discrimination and special measures (measures that eliminate racial discrimination). Racial discrimination concerns a certain act under certain conditions that nullifies or impairs the exercise or enjoyment of human rights and fundamental freedoms. Special measures are also known as affirmative action or positive discrimination and include a wide span of instruments, but need to be legitimate, necessary, appropriate, temporary, and respect the principles of fairness and proportionality. Although special measures do not constitute racial discrimination, they are no exception to racial discrimination. Instead, they are an integral part of the concept of eliminating discrimination and achieving equality. Thus, before one can consider a measure as a special measure, there needs to be racial discrimination. If that is the case, then the State is obliged to take special measures to protect those who need protection from racial discrimination. The Convention is very clear about the legal framework of racial discrimination and special measures. This article applies this legal framework to the current situation in Yogyakarta, Indonesia - where non-native Indonesian citizens cannot own land due to local government rules. When doing this, one can conclude that there is racial discrimination towards non-native Indonesian citizens. Therefore, this article recommends to the local government in Yogyakarta and the central government in Indonesia that they revoke this Governor Instruction. Moreover, the international community can take initiative and invoke responsibility from the political organs in Indonesia. A Special Rapporteur may make the difference and determine the presence of racial discrimination in Yogyakarta.
\end{abstract}

\section{Introduction}

In 1975, the Sultan of Yogyakarta issued a remarkable Governor Instruction. This Instruction contained rules differentiating the rights to land ownership between citizens of Indonesian descent and citizens who are not of Indonesian descent. For example, an

\footnotetext{
* 3rd Year Bachelor of Laws student (specialization International \& European Law) at the University of Groningen.
} 
Indonesian citizen whose parents are of Javanese descent can own land in Yogyakarta. However, an Indonesian citizen whose parents are of Chinese descent would not be able to own land under this rule. The reason for the enactment of this measure was the disparity of wealth between native and non-native citizens. On the one hand, the Instruction limited the rights of non-native citizens. On the other hand, it attempted to provide the opportunity for native citizens to achieve personal wealth. While non-native citizens have been deprived of their right to own land until this day, the current Sultan, Hamengkubuwono $\mathrm{X}$, insists that the policy is necessary as a safeguard to prevent property from being controlled by financially mighty non-native Indonesian citizens. ${ }^{1}$

Some argue that the controversial rule from 1975 is outdated and in violation of the Indonesian Constitution. After all, the Indonesian Constitution no longer recognises a distinction between native and non-native citizens. However, it seems that many do not know what international law says about the effect of this Instruction. Thus, the purpose of this article is to deliver an analysis of the legal framework of racial discrimination and special measures under the International Convention on the Elimination of All Forms of Racial Discrimination (ICERD) ${ }^{2}-$ a treaty to which Indonesia has been a State Party since 1999. ${ }^{3}$

First, this article will examine the concept of equality and non-discrimination. Before the ICERD was adopted, international law hardly employed the term 'racial discrimination'. On the contrary, most documents refer to equality and nondiscrimination. The birth of human rights brought this idea to life and due to its importance, eventually resulted in the adoption of a treaty in order to eliminate racial discrimination. The second section will concentrate on the definition and the nature of racial discrimination. There exists an obligation on States to protect their individuals from racial discrimination, the importance of which can be illustrated by the fact that it has been recognised as a peremptory norm of international law. The ICERD seems very clear about the definition of racial discrimination. However, this did not prevent the Committee on the Elimination of Racial Discrimination, the ICERD's treaty-body, from providing a general recommendation on this topic. Subsequently, the next section will address the legal framework of special measures under the ICERD. Special measures do not constitute racial discrimination. However, they are considered an integral part of the concept of eliminating racial discrimination and achieving equality.

Finally, by looking at the situation in Yogyakarta the last section will illustrate how the legal framework of racial discrimination and special measures is to be applied. Here, the article will examine whether the Governor Instruction constitutes racial discrimination or a special measure. Furthermore, this article will provide recommendations with regards to what the local government in Yogyakarta, the central government in Jakarta and the international community need to do. In the end, one should be able to understand the difficulties of truly eliminating all forms of racial discrimination and whether Indonesia can be held responsible for violating the ICERD.

1 Editorial, 'In Yogya, some are more equal than others' Jakarta Post (Jakarta 31 January 2017) at <https://www.pressreader.com/indonesia/the-jakarta-post/20170131/281505045943316> (accessed 23 August 2017).

2 International Convention on the Elimination of All Forms of Racial Discrimination (adopted 21 December 1965, entered into force 4 January 1969) 660 UNTS 195 (ICERD).

3 Ratification status by country or by treaty, at <http://tbinternet.ohchr.org/_layouts/treatybodyexternal /Treaty.aspx?CountryID=80\&Lang=en $>$ (accessed 23 August 2017). 


\section{Equality and Non-discrimination}

Racial discrimination, as a concept with its own legal framework, was not introduced until the early 1960s. The first fundamental legal instrument that addressed human rights, the Universal Declaration of Human Rights (UDHR) ${ }^{4}$, did not expressly address racial discrimination. However, the UDHR does include footholds with regards to the concept of equality and non-discrimination. First, the preamble talks about "the equal and inalienable rights of all members of the human family" and "the equal rights of men and women". ${ }^{5}$ Secondly, Article 1 states that "[a]11 human beings are born free and equal in dignity and rights' ${ }^{\prime}$ and Article 2 declares that '[e]veryone is entitled to all rights and freedoms set forth in this Declaration, without distinction of any kind. ${ }^{7}$ Thirdly, Article 7 reiterates the principle of non-discrimination by instructing that '[a]11 are equal before the law and are entitled without any discrimination to equal protection of the law. ${ }^{\prime}$

The UDHR - although a non-binding instrument - provided the inspiration for many subsequent human rights treaties that the international community acknowledges as part of modern-day human rights law. Hence, it has been fundamental for the so-called Bill of Human Rights, which consist of the UDHR together with the International Covenant on Civil and Political Rights (ICCPR) ${ }^{9}$ and the International Covenant on Economic, Social and Cultural Rights (ICESCR). ${ }^{10}$ Both covenants were adopted by the United Nations General Assembly (UNGA) in 1966 and entered into force ten years later.

The ICESCR particularly addresses social, economic and cultural rights. The provision of the ICESCR that primarily lays emphasis on the legal concept of equality and non-discrimination is Article 2 (2) which provides that ' $[t]$ he States Parties to the present Covenant undertake to guarantee that the rights enunciated in the present Covenant will be exercised without discrimination of any kind as to race, colour, sex, language, religion, political or other opinion, national or social origin, property, birth or other status'.11 According to the Committee on Economic, Social and Cultural Rights $(\mathrm{CESCR})^{12}$ Article 2 (2) prohibits direct and indirect discrimination. Furthermore, the Committee expressed the relevance of the requirement of States to ensure formal and substantive equality. This means that States are permitted to take positive action and may be required to do so in order to prevent discrimination. ${ }^{13}$

An equally worded provision has been adopted in the ICCPR, namely Article $2 .{ }^{14}$ Yet, an even more important provision on non-discrimination can be found in the

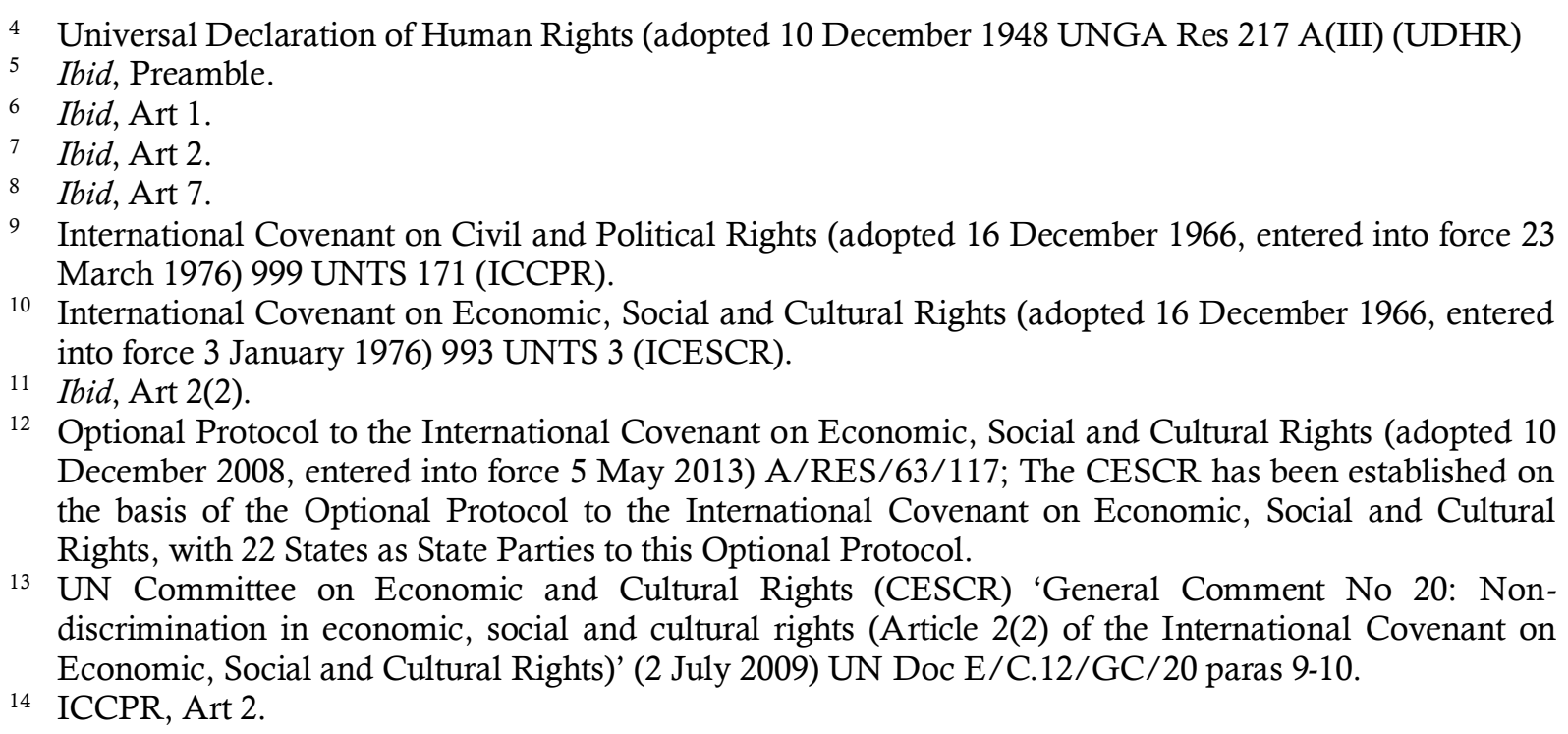

10 International Covenant on Economic, Social and Cultural Rights (adopted 16 December 1966, entered into force 3 January 1976) 993 UNTS 3 (ICESCR).

11 Ibid, Art 2(2).

12 Optional Protocol to the International Covenant on Economic, Social and Cultural Rights (adopted 10 December 2008, entered into force 5 May 2013) A/RES/63/117; The CESCR has been established on the basis of the Optional Protocol to the International Covenant on Economic, Social and Cultural Rights, with 22 States as State Parties to this Optional Protocol.

13 UN Committee on Economic and Cultural Rights (CESCR) 'General Comment No 20: Nondiscrimination in economic, social and cultural rights (Article 2(2) of the International Covenant on Economic, Social and Cultural Rights)' (2 July 2009) UN Doc E/C.12/GC/20 paras 9-10.

14 ICCPR, Art 2. 
ICCPR, namely Article 26. Contrary to Article 2, Article 26 needs to be considered as a more comprehensive provision that deals with non-discrimination:

All persons are equal before the law and are entitled without any discrimination to the equal protection of the law. In this respect, the law shall prohibit any discrimination and guarantee to all persons equal and effective protection against discrimination on any ground such as race, colour, sex, language, religion, political or other opinion, national or social origin, property, birth or other status. $^{15}$

Whereas Article 2 is a 'dependent' provision, Article 26 is 'free standing', i.e. it prohibits discrimination concerning all rights and benefits recognised by law - and not only those provided for in the ICCPR. ${ }^{16}$ This was explained in Broeks $v$ the Netherlands. ${ }^{17}$ Here, the Human Rights Committee (HRC) declared that the ICCPR requires that any right or benefit must be provided without discrimination when legislation provides so - even if there is no international obligation on the State to provide such rights or benefits in the first place. ${ }^{18}$

Nevertheless, States may derogate from their obligations set out in the ICCPR. According to its Article 4(1), measures derogating from the obligations set out in the covenant may be taken in times of public emergency which threatens the life of the nation. ${ }^{19}$ In addition, paragraph 2 sets out explicit non-derogable provisions in the ICCPR. ${ }^{20}$ Interestingly, Article 4, paragraph 2 does not name Article 26 as an explicit non-derogable provision. However, the perception that one may simply derogate from Article 26 is incorrect. After all, there are certain elements of non-discrimination that cannot be derogated from under any circumstances. It is for that reason that paragraph 1 provides conditions ${ }^{21}$ - one of those being that the actions do not encompass discrimination just on the ground of race, colour, sex, language, religion or social origin. This shows the essence of the prohibition of non-discrimination and, hence, such an explicit notification with regards to the prohibition to derogate from article 26 is unnecessary. ${ }^{22}$

15 ICCPR, Art 26.

16 Hughes, $\mathrm{P}$ and Murphy, R, Non-Discrimination in International Law. A handbook for practitioners (Interights 2011) 27; To the contrary, Article 2 guarantees non-discrimination only with respect to the rights guaranteed by the ICCPR.

17 S. W. M. Broeks v. The Netherlands, Communication No 172/1984, UN Doc CCPR/C/OP/2 at 196 (1990).

18 Ibid; The HRC declared that "article 26 requires that legislation should prohibit discrimination". However, "it does not of itself contain any obligation with respect to the matter that may be provided for by the legislation". To the contrary, it stated that "when such legislation is adopted in the exercise of a State's sovereign power, then such legislation must comply with article 26 of the Covenant". This view was also used in the case Danning v the Netherlands; L.G. Danning v. the Netherlands, Communication No 180/1984, UN Doc CCPR/C/OP 2 at 2015 (1990).

19 ICCPR, Art 4(1).

20 ICCPR, Art 4(2); Paragraph 2 acknowledges that "No derogation from articles 6, 7, 8 (paragraphs I and 2), $11,15,16$ and 18 may be made under this provision."

21 Measures derogating from a state's obligation in the covenant may only occur when: (1) "[i]n time of public emergency which threatens the life of the nation and the existence of which is officially proclaimed", (2) "to the extent strictly required by the exigencies of the situation", (3) "provided that such measures are not inconsistent with their other obligations under international law" and (4) "do not involve discrimination solely on the ground of race, colour, sex, language, religion or social origin".

22 UN Human Rights Committee (HRC) 'CCPR General Comment No 29: Article 4: Derogations during a State of Emergency' (31 August 2001) UN Doc CCPR/C/21/Rev.1/Add/11 para 8. 
Evidently, the concept of equality has been one of the most important human rights since its introduction after World War II. Whereas the idea of equality and nondiscrimination has been set out in the UDHR, ICESCR and ICCPR, the UNGA adopted a resolution that specifically addressed the prohibition of racial discrimination, namely the Declaration on the Elimination of All Forms of Racial Discrimination (UNDERD). ${ }^{23}$ This was introduced to condemn all varieties of racial, religious and national hatred as a violation of the United Nations Charter ${ }^{24}$ and the UDHR. However, as this was merely a 'declaration' adopted by the UNGA, the document is not formally binding. Nevertheless, it did not take too long until the UN adopted a formally binding treaty.

\section{The Definition and Nature of Racial Discrimination}

The ICERD is the principal UN treaty that aims for equality ${ }^{25}$ and the elimination of racial discrimination, with the Committee on Elimination of Racial Discrimination (CERD) ${ }^{26}$ as its treaty body. According to the ICERD the term "racial discrimination" means:

[A]ny distinction, exclusion, restriction or preference based on race, colour, descent, or national or ethnic origin which has the purpose or effect of nullifying or impairing the recognition, enjoyment or exercise, on an equal footing, of human rights and fundamental freedoms in the political, economic, social, cultural or any other field of public life. ${ }^{27}$

Based on its first article, four acts can be considered as discriminatory in the light of the ICERD, namely a 'distinction', 'exclusion', 'restriction' or 'preference'. ${ }^{28}$ However, two conditions need to be met to declare such an act as discriminatory. First, the act should be based on race, colour, descent, national origin or ethnic origin. ${ }^{29}$ The drafters' intention was to cover all kinds of acts of discrimination among persons in its first paragraph, but only when they were based on motivations of a racial nature in the broader sense. The words 'colour', 'descent' and 'ethnic origin' did not bring major difficulties with them. However, a genuine problem arose with regards to 'national origin'. ${ }^{30}$ On the one hand, some argued to include the term 'national origin' because it meant something different from 'ethnic origin'. On the other hand, it was argued that a

23 United Nations Declaration on the Elimination of All Forms of Racial Discrimination (adopted 20 November 1963 UNGA Res 1904 (XVIII) (UNDERD).

24 Charter of the United Nations (adopted 26 June 1945, entered into force 24 October 1945) 1 UNTS XVI (UN Charter).

25 UN Committee on the Elimination of Racial Discrimination (CERD) 'General Recommendation No 32 The Meaning and scope of special measures in the International Convention on the Elimination of All Forms Racial Discrimination' (24 September 2009) UN Doc CERD/C/GC/32 para 6; The principle of equality governed by the ICERD combines both formal equality before the law and de facto equality in the enjoyment and exercise of human rights.

26 ICERD, Art 8; P Thornberry, 'Confronting Racial Discrimination: A CERD Perspective' (2005) 5 (2) Human Rights Review 239, 242-247; The CERD supervises the implementation of the ICERD. In that light, it gives general recommendations and gives specific recommendations based on annual reports. Moreover, the CERD can receive individual complaints, but this can only happen if the State Party has recognized the competence of the Committee to do so. Nonetheless, sending individual complaints to the CERD is not the only way. An example of another mechanism is the Special Rapporteur on Contemporary Forms of Racism, Racial Discrimination, Xenophobia and Related Intolerance.

27 ICERD, Art 1(1).

28 Ibid.

29 Ibid.

30 Lerner, N, The U.N. Convention on the Elimination of all Forms of Racial Discrimination. Reprint Revised by Natan Lerner (Brill Leiden 2015) 33. 
State might be made up of different nationalities but that all citizens acquired the same nationality. ${ }^{31}$ Although this discussion showed confusion between 'national origin' and 'nationality', an agreement was reached by adding paragraphs 2 and $3 .^{32}$ The latter determines that distinctions, exclusions, restrictions or preferences between citizens and non-citizens could not be considered as discriminatory acts, but that the ICERD does not interfere in the domestic legislation that distinguishes citizens from non-citizens. Neither does it mean that the ICERD modifies 'citizenship' and 'naturalization' as substantive and procedural norms. Therefore, the ICERD only upholds the principle that any nationality should not be discriminated against. ${ }^{33}$

The second condition for racial discrimination is that the act should have 'the purpose or the effect of nullifying or impairing the recognition, enjoyment or exercise, on an equal footing of human rights and fundamental freedoms in the political, economic, social, cultural or any field of public life'. ${ }^{34}$ The purpose concerns the subjective consideration that will define the discriminatory nature of the act, whereas the effect addresses the objective consequences. This means that it is not necessary that both the 'purpose' and 'effect' are present. One is enough to define the act as discriminatory. ${ }^{35}$ This is also confirmed by Article 2(1)(c), which was intended to prohibit any law or practice, which has the effect of creating, prolonged racial discrimination. In addition, particular actions may have varied purposes. Thus, a violation of the ICERD can be identified without any difficulty when the subjective consideration will define the discriminatory nature of the act. However, in light of finding an actual purpose, objective consequences can be useful. The intention of the drafters was to prohibit only racially motivated discrimination, so the word 'effect' may bring actions within the scope of the Convention despite the fact that a discriminatory purpose could not be established. An example is when the discriminatory purpose is hard to identify in statues, policies or programs, but the effect of it reveals a discriminatory purpose. ${ }^{36}$

However, the effect or consequence of actions undertaken for non-discriminatory reasons requires more information about the context and circumstances. Furthermore, in seeking to determine whether an action has an effect contrary to the ICERD, it is important that such action has an unjustifiable disparate impact upon a group distinguished by race, colour, descent, or national or ethnic origin. This understanding was addressed by the CERD in its General Recommendation No. $14 .{ }^{37}$ Here, the CERD clarified the definition of Article 1(1). In addition to the understanding that either the 'effect' or 'purpose' is necessary, it explained that the words 'based on' do not bear any different meaning from 'on the grounds of' in preambular paragraph 7 . Furthermore, the Committee stated that a differentiation of treatment does not constitute discrimination if the criteria for such differentiation are legitimate or fall within the scope of Article 1(4) which addresses affirmative actions. Hence, a 'preference' constitutes no discrimination when it is an affirmative action. ${ }^{38}$

The codification of racial discrimination in the ICERD illustrates the importance of its legal framework. Additionally, its significance is also reflected by its nature of being

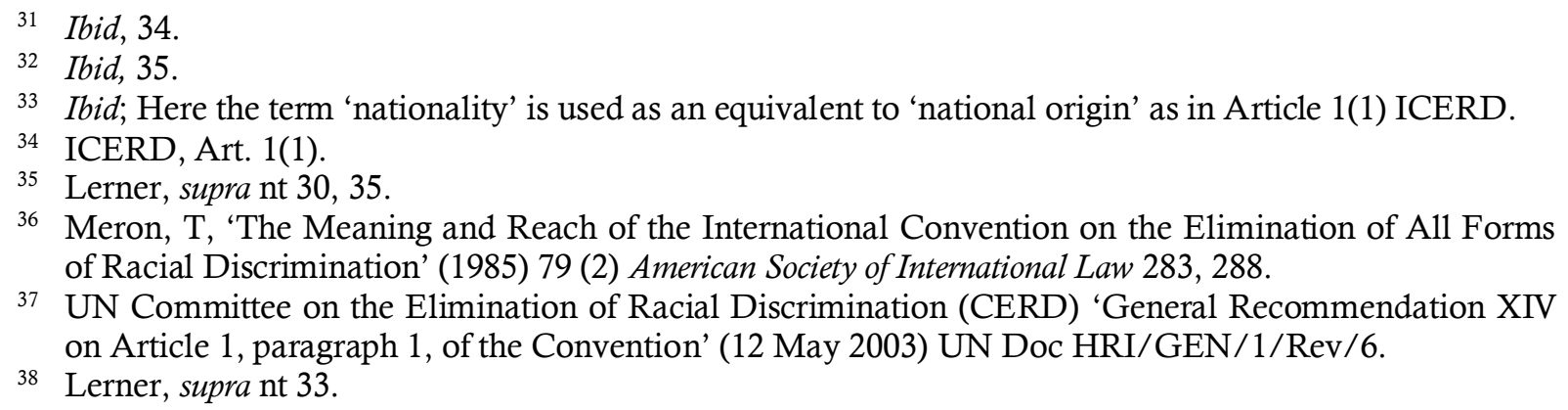


a jus cogens norm. It was only one decade after the adoption of the ICERD that the International Court (ICJ), first declared that racial discrimination is an obligation erga omnes. ${ }^{39}$ According to the Court, erga omnes norms are norms that concern an obligation owed to the international community as a whole..$^{40}$ In other words, obligations erga omnes are of a nature whereby all States have a legal interest in their performance. More than thirty years later, the International Law Commission (ILC) went one step further, and declared that the prohibition of racial discrimination is a jus cogens norm. ${ }^{41}$ Those are norms that are of such importance that they need to be considered as higher law from which no exception can be made.

Evidently there exists an obligation on States to protect individuals from racial discrimination. Its essence can be illustrated, first, by the adoption of the ICERD and, secondly, by its nature of being jus cogens and erga omnes. At first sight, the definition of racial discrimination under the ICERD seems deceptively straightforward. There needs to be a certain act by any actor that only under two conditions can constitute racial discrimination. However, according to its treaty body the scope of racial discrimination extends further to affirmative actions. It was for that reason that the CERD explained the scope and the definition of affirmative actions in its General Recommendation No. $32 .{ }^{42}$

\section{Special Measures under the ICERD}

Although affirmative actions have a long tradition on both the national and international level, there is no universally accepted terminology. Usually, a two-word term is employed that includes either the adjective 'positive' or 'affirmative' and the noun 'action' or 'discrimination'. In the US, the widely accepted term is affirmative action, whereas in Europe most authorities use the language of "discrimination". In France the most common term is discrimination positive, while in the $\mathrm{UK}$ it is positive discrimination and in Germany positive Diskriminierung or zulässige Diskriminierung. ${ }^{43}$ According to Bodduyt, affirmative action is both an international and a national legal concept that concerns a clear package of temporary measures. These measures have a specific object, namely to correct the position of members of a target group in one or more aspects in their social life. Respectively, this has the aim to obtain effective equality. ${ }^{44}$ The ICERD mentions neither affirmative action nor positive discrimination. Instead it refers to special measures in Article 1(4) and Article 2(2):

39 Barcelona Traction, Light and Power Company, Limited (Belgium $v$ Spain) (New Application: 1962) (Judgement) [1970] ICJ Rep 3 para 34.

$40 \quad$ Ibid, para 33.

41 ILC, 'Draft Articles on the Responsibility of States for Wrongful Acts, with commentaries' (2001) 2(2) Yearbook of the International Law Commission 31, 85 para 5; In its commentary regarding Article 26, the ILC made a list concerning jus cogens norms under contemporary international law. According to the Commission, "the peremptory norms that are clearly accepted and recognized include the prohibitions of aggression, genocide, slavery, racial discrimination, crimes against humanity and torture, and the right to self-determination."

42 General Recommendation No 32, supra nt 25.

43 Gerapetritis, G, Affirmative Action Policies and Judicial Review Worldwide (Springer 2016) 2.

44 UNCHR (Sub-Commission) 'Comprehensive Examination of Thematic Issues Relating To Racial Discrimination. The Concept of Practice of Affirmative Action. Preliminary Report Submitted by Mr. Marc Bossuyt, Special Rapporteur, in accordance with Sub-Commission resolution 1998/5' (19 June 2000) UN Doc E/CN.4/Sub.2/2000/11; C De la Vega, 'The Special Measures Mandate of The International Convention on the Elimination of All Forms of Racial Discrimination: Lessons From the United States and South Africa' (2010) 16 (3) 627, 640-641. 


\section{Article 1 (4)}

'Special measures taken for the sole purpose of securing adequate advancement of certain racial or ethnic groups or individuals requiring such protection as may be necessary in order to ensure such groups or individuals equal enjoyment or exercise of human rights and fundamental freedoms shall not be deemed racial discrimination, provided, however, that such measures do not, as a consequence, lead to the maintenance of separate rights for different racial groups and that they shall not be continued after the objectives for which they were taken have been achieved.'

\section{Article 2(2)}

'States Parties shall, when the circumstances so warrant, take, in the social, economic, cultural and other fields, special and concrete measures to ensure the adequate development and protection of certain racial groups or individuals belonging to them, for the purpose of guaranteeing them the full and equal enjoyment of human rights and fundamental freedoms. These measures shall in no case entail as a consequence the maintenance of unequal or separate rights for different racial groups after the objectives for which they were taken have been achieved.'

While Article 1(4) clarifies the meaning of discrimination when applied to special measures, Article 2(2) actually obliges State Parties to take special measures when the circumstances so warrant, for example, in the case of persistent disparities. ${ }^{45}$ One may think that the words 'when the circumstances so warrant' suggest that discretion is left to the State in deciding when remedial steps must be taken. ${ }^{46}$ However, the CERD holds a different view: '[ $t]$ he mandatory nature of the obligation is not weakened by the addition of the phrase "when the circumstances so warrant", a phrase that should be read as providing context for the application of the measures. ${ }^{47}$ In addition, the wording of Article 2 (2) may slightly differ from Article 1(4), but these differences do not affect their important unity of concept and purposes. ${ }^{48}$ Consequently, the requirements and limitations are in essence the same. ${ }^{49}$

The CERD takes the view that special measures are 'integral to the meaning and essential to the Convention's project of eliminating racial discrimination and advancing human dignity and effective equality'. ${ }^{50}$ Hence, a special measure is not an exception to racial discrimination. On the contrary, it is part of the concept of equality and nondiscrimination and it does not constitute discrimination under certain requirements. First, the measure needs to be legitimate. According to the CERD, a special measure is a measure that includes the full span of legislative, executive, administrative, budgetary and regulatory instruments and State Parties should include provisions on special measures in their legal systems. ${ }^{51}$ Secondly, the measure needs have the object of eliminating racial discrimination and achieving equality. According to the CERD, the concepts of equality and non-discrimination in the Convention extend to special

45 UN Committee on the Elimination of Racial Discrimination (CERD), 'Report of the Committee on the Elimination of Racial Discrimination (2001) UN Doc A/56/18 para 399.

46 Meron (n36) 306.

47 General Recommendation No 32, supra nt 25, para 30.

48 Ibid, para 29.

49 Ibid, para 35.

50 Ibid, para 20.

51 Ibid, para 13. 
measures. In other words, the objective of special measures is to establish equality, i.e. to secure the full and equal enjoyment of human rights and fundamental freedoms for disadvantaged groups. ${ }^{52}$ Thirdly, the measure needs to have a subject or target. According to the CERD, any group or person covered by Article 1 of the ICERD shall be considered as a beneficiary, hence, making the measures in principle available to them. This is clearly evidenced by the travaux préparatoires of the ICERD, the practice of State Parties, and relevant concluding observations of the CERD.$^{53}$ In addition, the span of potential beneficiaries of special measures should be understood in light of the general object of the ICERD, namely achieving equality and eliminating all forms of racial discrimination. ${ }^{54}$ Fourthly, the measure needs to have a specific function - which is preventive and corrective. ${ }^{55}$ After all, in light of the ICERD the beneficiaries need 'protection' from violations of human rights. Here, the term 'human rights' is not limited to a closed list of fundamental freedoms. In principle, special measures can affect the denial of all types of human rights, including enjoyment of any of the rights listed in Article 5 of the ICERD. ${ }^{56}$ Moreover, the violation of human rights can originate from any source. This also includes discriminatory activities of private persons.

Finally, the measure needs to have the 'sole purpose of securing adequate advancement'. ${ }^{57}$ This means that under the ICERD, the acceptable motivations for special measures are limited to securing adequate advancement. ${ }^{58}$ To determine what constitutes adequate advancement, it is extremely important to prioritise the wishes of the beneficiaries over what the person who takes the measure interprets as advancement. After all, having unwanted material benefits imposed upon them does not advance the beneficiaries. ${ }^{59}$ Besides that, the wishes of the beneficiaries need to be measured in a realistic review of the current situation of the individuals and communities concerned. Thus, concluding that the measure is necessary needs to be based on accurate data. ${ }^{60}$

Consequently, the disadvantaged position of one group compared to other groups in society, implies the need for certain goal-directed programmes that protect the beneficiaries from racial discrimination and have the objective of improving and remedying the disparities. ${ }^{61}$ These disparities include, but are not restricted to, consistent or systematic disparities and de facto inequalities resulting from history. So, it is not necessary to prove historic discrimination to employ special measures when these disparities continuously keep denying vulnerable groups the advantage of developing their human personality. Instead, emphasis needs to be placed on the correction of present disparities and the prevention of future inequality. A corresponding understanding would be more in conformity with the ICERD. At the end of the day, the focus of the Convention is the upholding of current responsibilities of State Parties. ${ }^{62}$

52 Ibid, paras 10-11.

53 Ibid, para 24.

$54 \quad$ Ibid, para 25.

55 Ibid, para 23.

56 Ibid, para 33.

57 ICERD, Art 1(4).

58 In other words, the measure is only appropriate when it secures adequate advancement.

59 Gerhardy v Brown [1985], 159 CLR 70, 135; P Thornberry, The International Convention On The Elimination Of All Forms Of Racial Discrimination. A Commentary (Oxford University Press 2016) 226; Thornberry uses Gerhardy v Brown as an example of the understanding of 'advancement'.

60 General Recommendation No 32, supra nt 25, para 17.

$61 \mathrm{Ibid}$, para 22; the ICERD uses the words "adequate advancement". This implies these goal-directed programmes.

62 Ibid; Thornberry, supra nt 59, 225. 
Yet, even if all the requirements for a legitimate special measure have been fulfilled, one cannot conclude than special measures have a never-ending scope. To the contrary, they are subject to limitations. First, the measure 'should not lead to the maintenance of separate rights for different racial groups'. This calls to mind the practice of Apartheid as mentioned in Article 3 ICERD. Secondly, the special measure 'shall not be continued after the objectives for which they have been taken have been achieved' ${ }^{63}$ According to the CERD, this limitation is primarily functional and goal-related. The application of measures should cease when the objectives for which they were created have been sustainably achieved. Therefore, special measures need to be cautiously tailored to satisfy the exact needs of the potential beneficiaries. ${ }^{64}$ However, a State should thoughtfully determine - especially when the special measure has been established for a long time - whether negative human rights consequences may arise for the beneficiaries as a result of its rapid withdrawal ${ }^{65}$ The rationale behind this is the significance of special measures. After all, States are obliged to use special measures when racial discrimination occurs. ${ }^{66}$

Special measures need to be understood as part of the concept of eliminating discrimination and, hence, achieving equality. Thus, even though, the ICERD mentions special measures in a slightly different way in two articles, this does not disrupt their complementary nature. The first provision basically declares that special measures do not constitute racial discrimination, while the second provision sets out the obligation for States to apply special measures when there is racial discrimination. The CERD seems to be very clear in its understanding of special measures being part of the elimination of racial discrimination and achieving equality. However, interpretations may diverge from reality. Consequently, the interesting question arises as to whether the present application of the Governor Instruction in Yogyakarta can be regarded as a special measure.

\section{A Critical Analysis of the Case in Yogyakarta: Special Measure or Racial Discrimination?}

When appropriate, special measures are persuasive tools to eliminate racial discrimination and achieve equality. Thus, in order to determine whether the Governor Instruction concerns a special measure, there needs to be racial discrimination first. One may argue that emphasis should be put on the circumstances in 1975 - the year that the Instruction was issued. So, in that case the question would be whether there was racial discrimination towards native citizens in 1975. However, this is an incorrect interpretation. To the contrary, concentrating on disparities in society in 2017 would be the most appropriate approach. After all, the CERD is very clear: emphasis should be put on present-day and future disparities. In other words, it is not necessary to prove historic discrimination to use special measures. Consequently, the question whether there is racial discrimination in 2017 needs to be answered.

When applying the legal framework of racial discrimination to the situation in 2017 one can observe that the Instruction prefers native Indonesian citizens to non-native citizens when it comes to land ownership. Thus, there is evidently a distinction, as the Instruction distinguishes groups of people based on descent that has the effect of

63 ICERD, Art 1(4).

64 General Recommendation No 32, supra nt 25, para 27; UN Committee on Economic, Social and Cultural Rights (CESCR) 'General Comment No 20 Non-discrimination in economic, social and cultural rights (Article 2 (2) of the International Covenant on Economic Social and Cultural Rights) para 9.

65 General Recommendation No 32, supra nt 25, para 35.

66 ICERD, Art 2(2). 
nullifying the exercise and enjoyment of human rights and fundamental freedoms, namely the right to property. ${ }^{67}$ Secondly, the Instruction clearly excludes non-natives based on their descent that consequently leads to the situation whereby non-natives cannot own property. However, the Instruction does concern a preference. Nevertheless, this regards a preference towards natives based on their descent that has not the purpose or effect of nullifying their exercise and enjoyment of owning land. Instead, it has improved their position and worsened the position for non-natives with regards to having land rights. All in all, the Instruction obviously illustrates racial discrimination towards non-native citizens.

The argument that the Governor Instruction concerns a special measure has no sufficient legal basis under the ICERD. Special measures have the objective of eliminating racial discrimination and achieving equality. These measures are necessary and the acceptable motivations are limited to only goal-directed programmes that protect the beneficiaries from racial discrimination. Their function is preventive and corrective, and racial discrimination in the present day needs to be proven to employ special measures. Currently, this is not the case for native citizens in Yogyakarta. Evidently, they are not suffering discrimination. Yet, one may argue that the Instruction had to be considered as a special measure but that it has lost its status of being 'special'. However, this line of argument is irrelevant as the only question that matters is whether the measure constitutes a special measure at the present time. This would be an interpretation more in line with the ICERD.

As the local government in Yogyakarta discriminates against non-native citizens, the State has the obligation to nullify laws that have the effect of racial discrimination ${ }^{68}$ and to take special measures. ${ }^{69}$ Therefore, this article puts forward two recommendations. First, the local government of Yogyakarta should revoke the Instruction as it clearly discriminates against non-native citizens. The role of the central government of Indonesia is crucial here. Yogyakarta is a 'special region' in Indonesia and, hence, it possesses an enormous amount of autonomy where culture and tradition are highlighted. For that reason, the region of Yogyakarta is considered as a monarchy within the unitary State of Indonesia with the Sultan as the Governor. So, the central government should negotiate with the local government of Yogyakarta and recommend that the Sultan revoke the Instruction.

Secondly, the international community needs to step up. Combatting racial discrimination from only within the domestic legal system is inadequate. The fight against racial discrimination requires a multi-level approach. Thus, pressure from an external dimension in the form of lobbying on the international level and letting other States invoke the responsibility of Indonesia through the UN human rights system is vital. Within the UN System, the United Nations Human Rights Council (UNHRC) is the subsidiary body of the UNGA that is responsible for promoting and protecting human rights. ${ }^{70}$ It is this human rights body that has given a mandate to the Special Rapporteur on Contemporary Forms of Racism, Racial Discrimination, Xenophobia and Related Intolerance to focus on a number of issues that relate to racial discrimination. ${ }^{71}$

67 ICERD, Article 5(d)(v).

68 ICERD, Art 2(1).

69 ICERD, Art 2(2); The ICERD clearly distinguishes two types of obligations. The first paragraph deals with obligations of States to adopt measures to eliminate racial discrimination, whereas the second paragraph deals with the problem of special measures for 'under-developed or under-privileged groups'. For a more extensive analysis see Lerner, supra nt 30, 40-44.

70 MN Shaw, International Law (Cambridge University Press 2014) 221-222 and 881.

71 UNHRC Res 7/34 (28 March 2008) UN Doc A/HRC/RES/7/34. 
In accordance with his mandate he undertakes inter alia fact-finding country visits ${ }^{72}$ and can declare the presence of racial discrimination where present. It is for that reason that the international community should urge the Special Rapporteur to review the situation in Yogyakarta. The results of his findings can be used as an instrument to put, subsequently, more pressure on the central government in Jakarta and the local government in Yogyakarta to revoke this Governor Instruction.

\section{Conclusion}

The concept of equality and non-discrimination constitutes a fundamental principle in international law. In the aftermath of World War II, this principle has developed by means of the adoption of the UDHR. Although the UDHR was not binding and only set out the idea of equality, the stepping stones for the concept of equality and nondiscrimination were the introductions of the ICESCR, ICCPR and, most importantly, the treaty that aims for equality and the elimination of discrimination: the ICERD.

In conclusion, Indonesia can be held responsible for violating a norm of international law that constitutes a rule of jus cogens and an erga omnes obligation and has been codified in the ICERD. The Governor Instruction in Yogyakarta clearly discriminates against non-native Indonesian citizens with regards to the full and equal exercise and enjoyment of the right to property. Therefore, the local government of Yogyakarta should revoke the Instruction. However, combatting racial discrimination should not only happen on the domestic level. The international community adopted the ICERD for a reason. For that same reason, the international community as a whole should take initiative. Human rights organizations should lobby on the case of Yogyakarta and States should invoke responsibility in political organs. Hence, pressure can be put on Indonesia to agree to invite the Special Rapporteur on Contemporary Forms of Racism, Racial Discrimination, Xenophobia and Related Intolerance to review the situation. The road towards elimination of discrimination seems long, but a report by the Special Rapporteur may constitute light at the end of the tunnel, as it would ensure increasing pressure on the local and central governments to revoke the Instruction.

www.grojil.org

72 Ibid, para 6; Though, important to note is that the Special Rapporteur can only come to Yogyakarta if Indonesia agrees to invite him. 